\title{
Human papilloma viruses
}

Denise A Galloway

From 17th International Symposium on HIV and Emerging Infectious Diseases (ISHEID)

Marseille, France. 23-25 May 2012

A group of approximately 13 human papillomaviruses (HPVs) are responsible for virtually all cervical cancers as well as the majority of vulvar, vaginal anal and penile cancers, as well as at least half of oropharyngeal cancers. Currently two prophylactic vaccines are highly efficacious in preventing HPV 16 and 18 associated disease, and the quadrivalent vaccine also prevents HPV 6 and 11 warts. Currently therapeutic vaccines targeting the viral E6 and E7 oncogenes are being developed. One topic that will be discussed is whether the prophylactic vaccine can have utility in any setting where individuals are already infected. Secondly, this review will discuss the basis of long-term immunity and whether it is afforded by both vaccination and natural infection. Finally, strategies to provide more broad based coverage to other HPV types will be discussed.

Published: 25 May 2012

doi:10.1186/1742-4690-9-S1-123

Cite this article as: Galloway: Human papilloma viruses. Retrovirology

2012 9(Suppl 1):123.

Fred Hutchinson Cancer Research Center, Seattle, USA

Submit your next manuscript to BioMed Central and take full advantage of:

- Convenient online submission

- Thorough peer review

- No space constraints or color figure charges

- Immediate publication on acceptance

- Inclusion in PubMed, CAS, Scopus and Google Scholar

- Research which is freely available for redistribution (c) 2012 Galloway; licensee BioMed Central Ltd. This is an Open Access article distributed under the terms of the Creative Commons Attribution License (http://creativecommons.org/licenses/by/2.0), which permits unrestricted use, distribution, and reproduction in any medium, provided the original work is properly cited. 